\title{
Impaired development of pancreatic beta-cell mass is a primary event during the progression to diabetes in the GK rat
}

\author{
J. M ovassat, C. Saulnier, P. Serradas, B . Portha \\ Physiopathology of Nutrition Laboratory, CNRS URA 307, Université Paris 7 - D. Diderot, Paris, France
}

Summary In the endocrine pancreas of the GK rat, a genetic model of non-insulin-dependent diabetes mellitus (NIDDM), it is not clear whether the histopathological changes reported up to now are related to the pathogenesis of hyperglycaemia or whether they occur secondarily to metabolic alterations. Using GK rats from the Paris colony, our study chronicles for the first time the pathophysiologic changes that occur in the GK pancreas from the late fetal period (day 21.5) until adult age (18 weeks). As compared to Wistar controls, GK fetuses exhibited higher plasma glucose level, lower plasma insulin level and normal plasma glucagon level. Their pancreatic insulin content and the relative volume and the total mass of their beta cells were sharply decreased, representing only 23,38 and $23 \%$ of control values, respectively. During the period from 4 days to 14 days after birth, GK neonates exhibited normal basal plasma glucose and glucagon levels despite decreased plasma insulin level. Their pancreatic insulin content represented only $31-40 \%$ of values found in the agerelated control pancreases and their total beta-cell mass was only $35 \%$ on day $4,30 \%$ on day 7 and $37 \%$ on day 14 . The adult diabetic GK rats exhibited higher basal plasma glucose and insulin levels while their basal plasma glucagon level remained normal. Their pancreatic insulin content and the total betacell mass remained decreased, representing only $32 \%$ and $47 \%$ of control values, respectively. Moreover, the adult GK pancreases exhibited noticeable alteration in the architecture of the large islet subpopulation which displayed considerable fibrosis with clusters of beta cells widely separated from each other by strands of connective tissue. Concerning the development of alpha cells in the GK rats, their relative volume was found to be normal during fetal and early neonatal periods. It was found to be moderately decreased (representing $64-67 \%$ of corresponding control values) in 14-day-old neonates and adult GK rats. Our findings demonstrate that in the GK rat, the deficit of total beta-cell mass as observed in the adult animal is related to impaired beta-cell development. The restriction of the betacell mass must be considered as a primary and crucial event in the sequence leading to overt diabetes in this NIDDM model. [Diabetologia (1997) 40: 916-925]

Keywords Beta-cell development, beta-cell mass, alpha-cell mass, pathogenesis, GK rat, non-insulin-dependent diabetes mellitus
Established non-insulin-dependent diabetes mellitus (NIDDM) is associated with profound insulin

Received: 6 February 1997 and in revised form: 21 April 1997

Corresponding author: Professor B. Portha, Laboratoire de Physiopathologie de la Nutrition, CNRS URA 307, Université Paris 7/D. Diderot, 2 place Jussieu, F-75251 Paris Cedex 05, France

A bbreviations: NIDDM, Non-insulin-dependent diabetes mellitus; TR, Texas red; FITC, fluorescein isothiocyanate. secretory defects that occur together with insulin resistance. The basis for the insulin secretory defects is unknown and is difficult to study in human subjects because it is not possible to identify prospectively those subjects in whom glucose control will deteriorate. The fact that total beta-cell mass is decreased in NIDDM patients compared to weight-matched control subjects [1] offers strong support for the notion that insulin production may become insufficient if beta-cell growth is deficient. The contribution of decreased beta-cell mass to deficient insulin secretion 
has been addressed in several animal model studies, though with conflicting conclusions [2]. The GK rat is a genetic non-overweight NIDDM model progressively characterized by Goto et al. [3]. This spontaneous diabetic state was produced by selective breeding (with glucose intolerance as a selection index) repeated over many generations, starting from a non-diabetic Wistar rat colony. All offspring had a diabetic glucose tolerance test after F10 and the diabetic state became stable after F30. In 1988, we initiated a colony of GK rats in Paris, starting with progenitors issued from F35 of the Japanese colony. All the adult rats obtained so far in our centre have had mild basal hyperglycaemia and impaired glucose tolerance and their diabetic state was stable over 18 months of follow-up [4]. In adult GK rats, pancreatic insulin stores were decreased by $60 \%$ and their total beta-cell mass was depleted by $50 \%$ [5]. Plasma insulin release in vivo in response to intravenous glucose was lacking and in vitro studies of insulin release with isolated perfused pancreas or perifused islets [6] indicated that both early and late phases of glucose-induced insulin release were markedly affected in the adult GK rat. Other studies using GK rats originating from local colonies have also documented an impaired insulin secretory response $[7,8]$. Nevertheless it was claimed that such impairment in the London colony was not related to a reduced pancreatic insulin content [8], whereas decreased as well as normal pancreatic insulin content, together with normal islet beta-cell density, have been reported in adult GK rats in the Stockholm colony $[7,9,10]$. These conflicting data led us to document more extensively the beta-cell mass in GK rats originating from the Paris colony. Moreover since all the GK rats become overtly diabetic between 3 and 4 weeks of age (J. Movassat and $\mathrm{D}$. Bailbé, unpublished observation), the predictable and standardized pattern of development of their NIDDM allows the beta-cell mass to be studied in the prediabetic stage and the results to be compared with those obtained in developing non-diabetic control Wistar rats. Taking advantage of this unique opportunity in the GK model, we have performed a longitudinal study of their endocrine pancreas from the late fetal life until adult age. We have determined the masses of beta and alpha cells using immunocytochemistry and morphometry, in 21.5-day-old fetuses, 4, 7 and 14-day-old newborns and 18-week-old adult GK rats. We also studied in parallel the changes of pancreatic and plasma insulin and glucagon levels.

\section{Materials and methods}

\section{A nimals}

Diabetic GK rats were obtained from our local colony initiated in Paris in 1988 [6] with progenitors issued from the original colony established by Goto et al. [3]. Non-diabetic Wistar rats were used as control animals. All animals were fed ad libitum with a commercial pelleted chow (diet 113, Usine dÁlimentation Rationnelle, Villemoisson-sur-Orge, France). For this study 21.5-day-old fetuses, 4, 7, 14-day-old neonates and adult animals (18-week-old) were used.

Fetuses. Pregnant female rats were killed by cervical dislocation at day 21.5 of pregnancy and their fetuses rapidly removed. Blood samples were collected from the axillary vessels.

Neonates. The age of the neonates was determined from the day of birth (usually day 22.5 post coïtum in both GK and non-diabetic Wistar mothers) considered as day 1 neonatal. Each newborn litter was limited to $8-10$ pups by removal of additional pups on the day of birth. The animals were killed by decapitation and blood samples were collected.

A dults. Non-fasting 18-week-old adult male animals were weighed and blood was withdrawn from the tail vein. In all groups studied, blood samples were immediately centrifuged at $4{ }^{\circ} \mathrm{C}$ and plasma was stored at $-20^{\circ} \mathrm{C}$ until assayed. For glucagon assay, aprotinin was added to plasma before storage. For immunohistochemical study pancreases from 4 or 5 animals were removed, weighed, fixed in aqueous Bouin's solution overnight and embedded in paraplast as usual. The pancreases of the remaining animals were weighed after removal, homogenized and centrifuged at $4{ }^{\circ} \mathrm{C}$ in an acid-alcohol solution ( $75 \%$ ethanol, $1.5 \%$ HCL $12 \mathrm{~N}, 23.5 \%$ distilled water). The supernatant was stored at $-20^{\circ} \mathrm{C}$ until radioimmunoassayed for insulin and glucagon.

\section{I mmunohistochemistry and morphometry}

Each pancreatic block was serially sectioned $(7 \mu \mathrm{m})$ throughout its length to avoid any bias due to regional change in islet distribution and cell composition, and mounted on slides. Adjacent sections at a fixed interval through the block were immunostained for insulin and glucagon with a technique adapted from the peroxidase indirect labelling as previously described [11]. The anti-insulin serum was purchased from ICN (ref. 65104-1, ICN Pharmaceutical, Orsay, France); it was raised in the guinea-pig against porcine insulin. Labelling was performed using a peroxidase-conjugated rabbit anti-guinea pig IgG (ref. PO141, Dako, Trappes, France). The activity was revealed with 3,3'-diaminobenzidine-tetra-hydrochloride using a peroxidase substrate kit (DAB, Biosys-Vector, Compiègne, France). For glucagon staining, anti-glucagon serum (ref. 64-706-1, ICN) raised in rabbit and peroxidase-conjugated goat anti-rabbit IgG (ref. 076-15-06, KPL-Dynatech, St. Quentin-en-Yvelines, France) were used. Nuclei were stained with haematoxylin. After staining, sections were mounted in Eukitt. Quantitative evaluation was performed using a computer-assisted image analysis based on an Olympus $\mathrm{BH} 2$ microscope connected via a colour video camera to a Compac PC computer and using the software Imagenia 2000 (Biocom, les Ulis, France). The areas of the insulin and glucagon positive cells as well as the area of the total pancreatic cells were evaluated in each stained section. The alpha and beta-cell relative volumes were obtained by calculating the ratio between the area occupied by immunoreactive cells and the area occupied by total pancreatic cells according to stereological methods. The total alpha and beta-cell masses per pancreas were derived by multiplying the alpha or beta-cell relative volume by the total pancreatic weight.

In order to obtain a specific blue staining of the pancreatic connective tissue after brown DAB staining for insulin or glucagon, some sections in each group were treated according to 
Table 1. Body weight, pancreas weight and plasma glucose, insulin and glucagon levels of GK rats and non-diabetic Wistar rats as a function of age

\begin{tabular}{|c|c|c|c|c|c|c|}
\hline \multirow[t]{2}{*}{ Age } & \multirow[t]{2}{*}{ Rat } & \multirow{2}{*}{$\begin{array}{l}\text { Body weight } \\
{[\mathrm{g}]}\end{array}$} & \multirow{2}{*}{$\begin{array}{l}\text { Pancreas weight } \\
{[\mathrm{mg}]}\end{array}$} & \multicolumn{3}{|l|}{ Plasma } \\
\hline & & & & Glucose $[\mathrm{mmol} / \mathrm{l}]$ & Insulin $[\mathrm{ng} / \mathrm{ml}]$ & Glucagon $[\mathrm{pg} / \mathrm{ml}]$ \\
\hline Fetal (21.5 days) & Wistar & $4.6 \pm 0.1[59]$ & $25.9 \pm 0.8[22]$ & $3.9 \pm 0.2[112]$ & $19 \pm 1[112]$ & $455 \pm 17[44]$ \\
\hline 4 days & Wistar & $10.2 \pm 0.3[11]$ & $25.4 \pm 2[11]$ & $6.2 \pm 0.2[11]$ & $6.6 \pm 0.7[8]$ & $659 \pm 83[8]$ \\
\hline 4 days & GK & $6.0 \pm 0.2^{\mathrm{c}}[20]$ & $15.2 \pm 0.8^{c}[10]$ & $5.4 \pm 0.3[18]$ & $1.0 \pm 0.1^{\mathrm{c}}[10]$ & $646 \pm 78[7]$ \\
\hline 7 days & Wistar & $14.9 \pm 0.5[13]$ & $36.8 \pm 2.5[13]$ & $6.8 \pm 0.1[13]$ & $3.1 \pm 0.3[16]$ & ND \\
\hline 7 days & GK & $8.7 \pm 0.1^{\mathrm{c}}[18]$ & $17.9 \pm 0.6^{\mathrm{c}}[10]$ & $7.1 \pm 0.2[18]$ & $0.9 \pm 0.1^{\mathrm{c}}[15]$ & ND \\
\hline Adult (18 weeks) & Wistar & $431.1 \pm 7.9[12]$ & $1154 \pm 58[9]$ & $6.9 \pm 0.2[12]$ & $3.07 \pm 0.3[9]$ & $353 \pm 53[8]$ \\
\hline Adult (18 weeks) & GK & $346.2 \pm 7.6^{\mathrm{c}}[12]$ & $962 \pm 35^{\mathrm{b}}[10]$ & $9.7 \pm 0.7^{\mathrm{b}}[12]$ & $4.64 \pm 0.41^{\mathrm{a}}[16]$ & $331 \pm 41[8]$ \\
\hline
\end{tabular}

Values are expressed as mean \pm SEM. The number of animals is shown in parentheses. All animals were in the non-fasted state.

Heidenhain [12]: after mordanting in phosphotungstic acid, the sections were stained with an aniline blue/G orange mixture.

\section{Immunohistochemistry and confocal microscopy}

Paraffin sections $(7 \mu \mathrm{m})$ were exposed to a mixture of guinea pig anti-insulin and rabbit anti-glucagon antisera. Following rinses, the sites of the antigen-antibody reactions were detected with a mixture of Texas Red (TR)-conjugated anti-guinea pig IgG (ref TI-7000, Biosys-Vector) and fluorescein isothiocyanate (FITC)-conjugated anti-rabbit IgG (ref FI-1000, BiosysVector). Sections were mounted in Vectashield medium (ref H-1000, Biosys-Vector). Immunofluorescent specimens were examined in a Nikon epifluorescence microscope equipped with selective FITC and TR filters. All immunoreactive cells expressing one or two hormones were counted in an entire field. The same specimens were also examined in a confocal laser scan microscope (TCS4D, Leica). For fluorescein and TR excitations, this system uses an argon/krypton laser operating respectively with the $488 \mathrm{~nm}$ and 568 lines. The pinhole of the confocal system was adjusted to allow a field depth of about $0.5 \mu \mathrm{m}$. The two images could then be merged into a single colour image for comparing the distribution of positive immunoreactivity for each antibody.

Individual beta-cell area. Beta-cell size was determined on insulin-stained sections by evaluating the mean cross-sectional area of individual beta-cells. Beta-cell nuclei on a random section were counted, and the area of beta-cell tissue in that section, measured by planimetry as described before. The betacell area was divided by the number of nuclei to calculate the area of individual beta cells. Using this technique it must be recognized that the actual number of beta cells is probably higher than the number counted, since not all beta cells are sectioned across their nuclei and therefore the size of the beta cells is overestimated [13].

A nalytical techniques. Plasma glucose was determined with a glucose analyser (Beckman, Fullerton, Calif., USA). Immunoreactive insulin in the plasma and pancreases was estimated with purified rat insulin as standard (Novo, Copenhagen, Denmark) and antibodies to mixed (pork and beef) insulin, and pork $\left[{ }^{125} \mathrm{I}\right]$ monoiodinated insulin as tracer [5]. Charcoal was used to separate free from bound hormone. The method allows
${ }^{\mathrm{a}} \mathrm{p}<0.05 ;{ }^{\mathrm{b}} \mathrm{p}<0.01 ;{ }^{\mathrm{c}} \mathrm{p}<0.001$ as compared to age-related Wistar group.

ND, non-determined

the determination of $0.1 \mathrm{ng} / \mathrm{ml}$, with a coefficient of variation within and between assays of $10 \%$. Immunoreactive glucagon in the plasma and pancreases was estimated using a glucagon kit (Pharmacia, St. Quentin-en-Yvelines, France) with human glucagon as standard. The rabbit anti-glucagon antibody was highly specific for pancreatic glucagon and did not cross-react with gastrointestinal substances which present antigenic sites identical to that of glucagon. Monoiodinated $\left[{ }^{125} \mathrm{I}\right]$ glucagon was used as tracer. After incubation, free and bound hormones were separated using polyethyleneglycol. The method allows the determination of $14 \mathrm{pg} / \mathrm{ml}$ with a coefficient of variation within and between assays of $9 \%$.

Statistical analysis. Results are expressed as means \pm SEM. Tests of significance were made using Student's t-test.

\section{Results}

\section{Fetuses}

As shown in Table 1, the body weight was similar in 21.5-day-old GK and control fetuses. The weight of GK fetal pancreases was significantly lower than that of the controls. GK fetuses exhibited higher plasma glucose level than controls and their basal plasma insulin level was significantly decreased. No difference in plasma glucagon concentration was found between the two groups.

In both type of pancreas, beta cells were localized in the centre of the islets and the alpha cells formed a peripheral crown. Beta and alpha cells were well granulated in both groups. However in the GK fetuses, the islets were less numerous and smaller than in the controls (Fig. 1). The relative volume and the total beta-cell mass were sharply decreased in GK rats since the values of these two parameters represented only 38 and $23 \%$ of control values respectively (Fig.2). The pancreatic insulin content in GK fetuses was only $23 \%$ of the corresponding value in control fetuses. The mean insulin content per beta cell was similar in both groups (Table 2). 

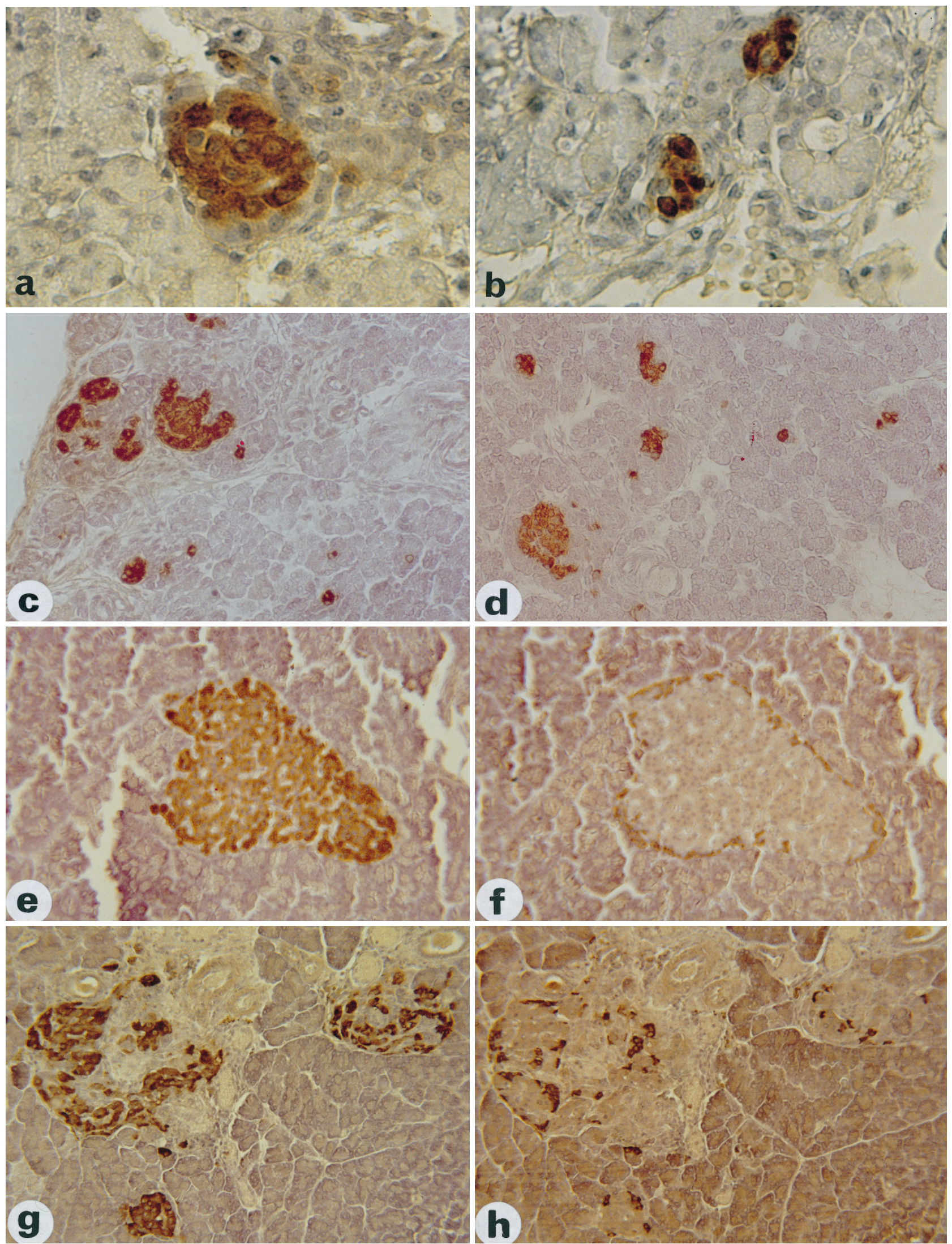

Fig. 1a-h. Indirect immunoperoxidase staining for insulin in 21.5-day-old Wistar (a) and GK (b) fetuses $(\times 325)$, in 7-day-old Wistar (c) and GK (d) neonates $(\times 160)$, and

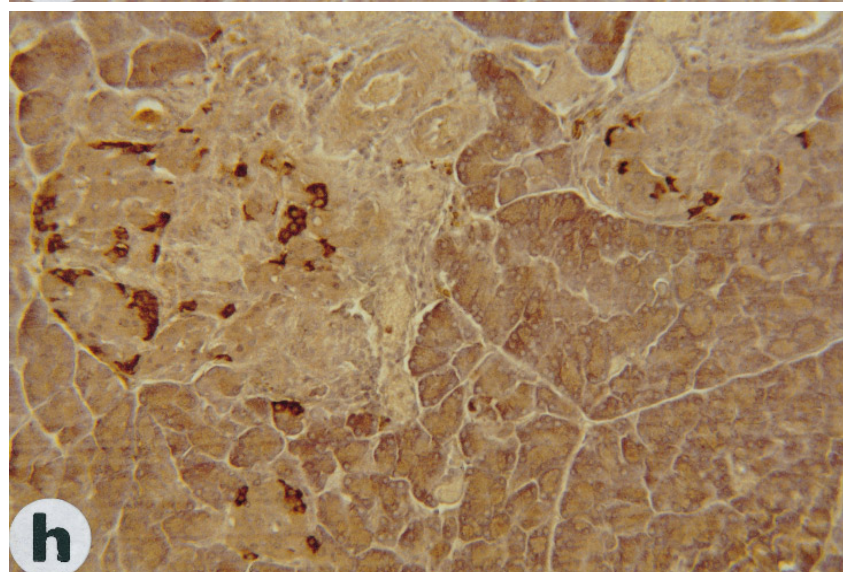

Indirect immunoperoxidase staining for glucagon in 18week-old Wistar (f) and GK (h) adults $(\times 125)$ in 18-week-old Wistar (e) and GK (g) adults $(\times 125)$. 
Table 2. Total pancreatic beta-cell mass and pancreatic insulin content of GK rats and non-diabetic Wistar rats as a function of age

\begin{tabular}{|c|c|c|c|c|c|c|c|c|}
\hline \multirow[t]{2}{*}{ Age } & \multirow[t]{2}{*}{ Rat } & \multicolumn{2}{|c|}{ Pancreatic insulin } & \multirow{2}{*}{$\begin{array}{l}\% \text { beta-cells } \\
\text { in pancreas }\end{array}$} & \multicolumn{3}{|l|}{ beta-cell mass } & \multirow{2}{*}{$\begin{array}{l}\text { Insulin content/ } \\
\text { beta-cell mass } \\
{[\mu \mathrm{g} / \mathrm{mg}]}\end{array}$} \\
\hline & & [ $\mu \mathrm{g} /$ pancreas] & {$[\mu \mathrm{g} / \mathrm{mg}$ pancreas] } & & [mg/pancreas] & [ $\mu \mathrm{g} / \mathrm{mg}$ pancreas] & {$[\mu \mathrm{g} / \mathrm{g}$ body wt] } & \\
\hline $\begin{array}{l}\text { Fetal } \\
\text { (21.5 days) }\end{array}$ & Wistar & $\begin{array}{l}4.7 \pm 0.2 \\
{[22]}\end{array}$ & $\begin{array}{l}0.18 \pm 0.01 \\
{[22]}\end{array}$ & $\begin{array}{l}0.81 \pm 0.04 \\
{[4]}\end{array}$ & $\begin{array}{l}0.195 \pm 0.026 \\
{[4]}\end{array}$ & $\begin{array}{l}8.24 \pm 0.37 \\
{[4]}\end{array}$ & $\begin{array}{l}42.4 \pm 5.6 \\
{[4]}\end{array}$ & $\begin{array}{l}24.1 \pm 1.2 \\
{[22]}\end{array}$ \\
\hline $\begin{array}{l}\text { Fetal } \\
\text { (21.5 days) }\end{array}$ & GK & $\begin{array}{l}1.11 \pm 0.04^{\mathrm{c}} \\
{[24]}\end{array}$ & $\begin{array}{l}0.07 \pm 0.002^{c} \\
{[24]}\end{array}$ & $\begin{array}{l}0.31 \pm 0.02^{c} \\
{[4]}\end{array}$ & $\begin{array}{l}0.045 \pm 0.002^{\mathrm{b}} \\
{[4]}\end{array}$ & $\begin{array}{l}3.11 \pm 0.22^{c} \\
{[4]}\end{array}$ & $\begin{array}{l}9.7 \pm 0.4^{b} \\
{[4]}\end{array}$ & $\begin{array}{l}24.7 \pm 0.9 \\
{[24]}\end{array}$ \\
\hline 4 days & GK & $\begin{array}{l}5.6 \pm 0.4^{\mathrm{c}} \\
{[5]}\end{array}$ & $\begin{array}{l}0.41 \pm 0.02^{\mathrm{c}} \\
{[5]}\end{array}$ & $\begin{array}{l}1.38 \pm 0.09^{\mathrm{b}} \\
{[4]}\end{array}$ & $\begin{array}{l}0.21 \pm 0.01^{\mathrm{b}} \\
{[4]}\end{array}$ & $\begin{array}{l}13.8 \pm 0.9^{c} \\
{[4]}\end{array}$ & $\begin{array}{l}29.7 \pm 1.4^{\mathrm{b}} \\
{[4]}\end{array}$ & $\begin{array}{l}26.8 \pm 2.2 \\
{[5]}\end{array}$ \\
\hline 7 days & Wistar & $\begin{array}{l}19.8 \pm 0.1 \\
{[13]}\end{array}$ & $\begin{array}{l}0.55 \pm 0.03 \\
{[13]}\end{array}$ & $\begin{array}{l}2.45 \pm 0.17 \\
{[4]}\end{array}$ & $\begin{array}{l}0.74 \pm 0.06 \\
{[4]}\end{array}$ & $\begin{array}{l}24.5 \pm 1.6 \\
{[4]}\end{array}$ & $\begin{array}{l}50.9 \pm 2.5 \\
{[4]}\end{array}$ & $\begin{array}{l}24.6 \pm 1.6 \\
{[4]}\end{array}$ \\
\hline 7 days & GK & $\begin{array}{l}6.3 \pm 0.4^{c} \\
{[5]}\end{array}$ & $\begin{array}{l}0.36 \pm 0.01^{b} \\
{[5]}\end{array}$ & $\begin{array}{l}1.23 \pm 0.09^{c} \\
{[4]}\end{array}$ & $\begin{array}{l}0.22 \pm 0.01^{\mathrm{c}} \\
{[4]}\end{array}$ & $\begin{array}{l}12.3 \pm 0.8^{c} \\
{[4]}\end{array}$ & $\begin{array}{l}24.7 \pm 1.4^{\mathrm{c}} \\
{[4]}\end{array}$ & $\begin{array}{l}28.9 \pm 2.1 \\
{[5]}\end{array}$ \\
\hline 14 days & GK & $\begin{array}{l}9.6 \pm 0.2^{\mathrm{c}} \\
{[5]}\end{array}$ & $\begin{array}{l}0.22 \pm 0.01^{b} \\
{[5]}\end{array}$ & $\begin{array}{l}0.90 \pm 0.09^{c} \\
{[4]}\end{array}$ & $\begin{array}{l}0.33 \pm 0.04^{\mathrm{c}} \\
{[4]}\end{array}$ & $\begin{array}{l}9.0 \pm 0.9^{c} \\
{[4]}\end{array}$ & $\begin{array}{l}16.6 \pm 2.2^{\mathrm{c}} \\
{[4]}\end{array}$ & $\begin{array}{l}29.1 \pm 0.8 \\
{[5]}\end{array}$ \\
\hline $\begin{array}{l}\text { Adult } \\
\text { (18 weeks) }\end{array}$ & Wistar & $\begin{array}{l}246 \pm 25 \\
{[5]}\end{array}$ & $\begin{array}{l}0.18 \pm 0.01 \\
{[5]}\end{array}$ & $\begin{array}{l}0.55 \pm 0.04 \\
{[4]}\end{array}$ & $\begin{array}{l}5.9 \pm 0.7 \\
{[4]}\end{array}$ & $\begin{array}{l}5.5 \pm 0.4 \\
{[4]}\end{array}$ & $\begin{array}{l}13.7 \pm 1.5 \\
{[4]}\end{array}$ & $\begin{array}{l}42.1 \pm 4.8 \\
{[5]}\end{array}$ \\
\hline $\begin{array}{l}\text { Adult } \\
\text { (18 weeks) }\end{array}$ & GK & $\begin{array}{l}78 \pm 11^{c} \\
{[5]}\end{array}$ & $\begin{array}{l}0.08 \pm 0.01^{\mathrm{c}} \\
{[5]}\end{array}$ & $\begin{array}{l}0.31 \pm 0.03^{b} \\
{[4]}\end{array}$ & $\begin{array}{l}2.8 \pm 0.2^{\mathrm{b}} \\
{[4]}\end{array}$ & $\begin{array}{l}3.1 \pm 0.3^{b} \\
{[4]}\end{array}$ & $\begin{array}{l}8.1 \pm 0.7^{\mathrm{a}} \\
{[4]}\end{array}$ & $\begin{array}{l}27.7 \pm 4.7 \\
{[5]}\end{array}$ \\
\hline
\end{tabular}

Values are expressed as mean \pm SEM. The number of animals is shown in parentheses. All animals were in the non-fasted state.

${ }^{\mathrm{a}} \mathrm{p}<0.05 ;{ }^{\mathrm{b}} \mathrm{p}<0.01 ;{ }^{\mathrm{c}} \mathrm{p}<0.001$ as compared to age-related Wistar group

Concerning the alpha cells, their relative volume in the GK pancreas was not different from that of controls. However the total alpha-cell mass and pancreatic glucagon content were decreased in GK fetuses

Fig. 2 A, B. Developmental changes of the beta-cell mass in pancreas of Wistar $(\bigcirc)$ and GK $(O)$ rats between fetal age (day 21.5) and adult age (18 weeks) (means \pm SEM). A Betacell mass per pancreas; B Beta-cell mass per mg pancreas. $* * p<0.01$, ***p $<0.001$ as compared to age-related controls

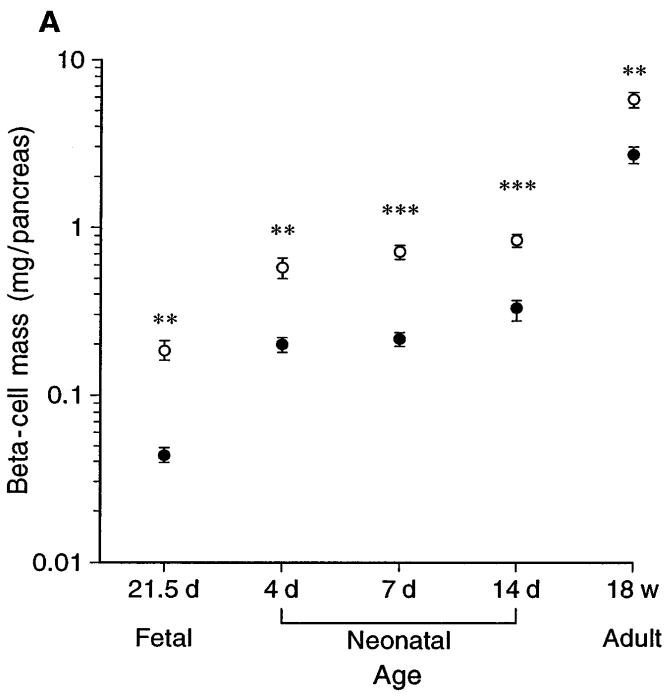

since their pancreatic weight was lower than that of the controls (Table 3).

\section{N eonates}

During the follow-up period ranging from 4 days to 14 days after birth (Table 1), GK neonates exhibited lower body weight and pancreatic weight than controls. Their basal plasma glucose level was not significantly different from that of controls. By contrast their

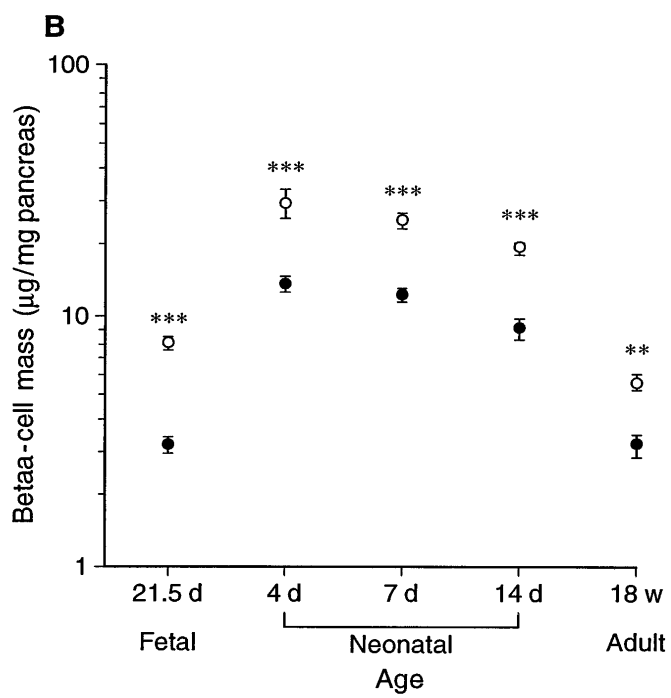


Table 3. Total pancreatic alpha-cell mass and pancreatic glucagon content of non-diabetic Wistar rats and GK rats as a function of age

\begin{tabular}{|c|c|c|c|c|c|c|c|c|}
\hline \multirow[t]{2}{*}{ Age } & \multirow[t]{2}{*}{ Rat } & \multicolumn{2}{|c|}{ Pancreatic glucagon } & \multirow{2}{*}{$\begin{array}{l}\% \text { alpha-cells } \\
\text { in pancreas }\end{array}$} & \multicolumn{3}{|l|}{ alpha-cell mass } & \multirow{2}{*}{$\begin{array}{l}\text { Glucagon content/ } \\
\text { alpha-cell mass } \\
{[\mu \mathrm{g} / \mathrm{mg}]}\end{array}$} \\
\hline & & [ $\mu \mathrm{g} /$ pancreas] & [ $\mu \mathrm{g} / \mathrm{g}$ pancreas] & & [ $\mu \mathrm{g} /$ pancreas $]$ & {$[\mu \mathrm{g} / \mathrm{mg}$ pancreas] } & [ $\mu \mathrm{g} / \mathrm{g}$ body wt] & \\
\hline $\begin{array}{l}\text { Fetal } \\
\text { (21.5 days) }\end{array}$ & Wistar & $\begin{array}{l}0.18 \pm 0.01 \\
{[22]}\end{array}$ & $\begin{array}{l}7.1 \pm 0.3 \\
{[22]}\end{array}$ & $\begin{array}{l}0.25 \pm 0.03 \\
{[4]}\end{array}$ & $\begin{array}{l}58 \pm 8 \\
{[4]}\end{array}$ & $\begin{array}{l}2.5 \pm 0.3 \\
{[4]}\end{array}$ & $\begin{array}{l}12.5 \pm 1.8 \\
{[4]}\end{array}$ & $\begin{array}{l}3.1 \pm 0.1 \\
{[22]}\end{array}$ \\
\hline $\begin{array}{l}\text { Fetal } \\
\text { (21.5 days) }\end{array}$ & GK & $\begin{array}{l}0.12 \pm 0.01^{\mathrm{c}} \\
{[24]}\end{array}$ & $\begin{array}{l}7.4 \pm 0.3 \\
{[24]}\end{array}$ & $\begin{array}{l}0.21 \pm 0.03 \\
{[4]}\end{array}$ & $\begin{array}{l}30 \pm 4^{\mathrm{a}} \\
{[4]}\end{array}$ & $\begin{array}{l}2.1 \pm 0.3 \\
{[4]}\end{array}$ & $\begin{array}{l}6.4 \pm 0.8^{\mathrm{a}} \\
{[4]}\end{array}$ & $\begin{array}{l}4.1 \pm 0.2^{\mathrm{a}} \\
{[24]}\end{array}$ \\
\hline 4 days & Wistar & $\begin{array}{l}0.86 \pm 0.01 \\
{[5]}\end{array}$ & $\begin{array}{l}28 \pm 3 \\
{[5]}\end{array}$ & $\begin{array}{l}1.81 \pm 0.29 \\
{[4]}\end{array}$ & $\begin{array}{l}359 \pm 46 \\
{[4]}\end{array}$ & $\begin{array}{l}18 \pm 3 \\
{[4]}\end{array}$ & $\begin{array}{l}39 \pm 5 \\
{[4]}\end{array}$ & $\begin{array}{l}2.4 \pm 0.2 \\
{[5]}\end{array}$ \\
\hline 4 days & GK & $\begin{array}{l}0.43 \pm 0.06^{\mathrm{c}} \\
{[5]}\end{array}$ & $\begin{array}{l}30 \pm 3 \\
{[5]}\end{array}$ & $\begin{array}{l}1.54 \pm 0.04 \\
{[4]}\end{array}$ & $\begin{array}{l}236 \pm 16^{\mathrm{a}} \\
{[4]}\end{array}$ & $\begin{array}{l}15 \pm 1 \\
{[4]}\end{array}$ & $\begin{array}{l}33 \pm 1 \\
{[4]}\end{array}$ & $\begin{array}{l}1.8 \pm 0.3 \\
{[5]}\end{array}$ \\
\hline 7 days & Wistar & $\begin{array}{l}1.3 \pm 0.2 \\
{[5]}\end{array}$ & $\begin{array}{l}28.3 \pm 4.2 \\
{[5]}\end{array}$ & ND & ND & ND & ND & ND \\
\hline 7 days & GK & $\begin{array}{l}0.7 \pm 0.1^{\mathrm{a}} \\
{[5]}\end{array}$ & $\begin{array}{l}40 \pm 4 \\
{[5]}\end{array}$ & ND & ND & ND & ND & ND \\
\hline 14 days & Wistar & $\begin{array}{l}2.3 \pm 0.3 \\
{[5]}\end{array}$ & $\begin{array}{l}35 \pm 5 \\
{[5]}\end{array}$ & $\begin{array}{l}1.28 \pm 0.11 \\
{[4]}\end{array}$ & $\begin{array}{l}661 \pm 60 \\
{[4]}\end{array}$ & $\begin{array}{l}13 \pm 1 \\
{[4]}\end{array}$ & $\begin{array}{l}24 \pm 3 \\
{[4]}\end{array}$ & $\begin{array}{l}3.3 \pm 0.4 \\
{[5]}\end{array}$ \\
\hline 14 days & GK & $\begin{array}{l}1.2 \pm 0.1 \\
{[5]}\end{array}$ & $\begin{array}{l}27 \pm 2 \\
{[5]}\end{array}$ & $\begin{array}{l}0.82 \pm 0.09^{\mathrm{a}} \\
{[4]}\end{array}$ & $\begin{array}{l}296 \pm 22^{\mathrm{b}} \\
{[4]}\end{array}$ & $\begin{array}{l}8 \pm 1^{a} \\
{[4]}\end{array}$ & $\begin{array}{l}15 \pm 1^{\mathrm{a}} \\
{[4]}\end{array}$ & $\begin{array}{l}3.9 \pm 0.3 \\
{[5]}\end{array}$ \\
\hline $\begin{array}{l}\text { Adult } \\
\text { (18 weeks) }\end{array}$ & Wistar & $\begin{array}{l}3.2 \pm 0.4 \\
{[5]}\end{array}$ & $\begin{array}{l}2.3 \pm 0.3 \\
{[5]}\end{array}$ & $\begin{array}{l}0.09 \pm 0.01 \\
{[4]}\end{array}$ & $\begin{array}{l}917 \pm 70 \\
{[4]}\end{array}$ & $\begin{array}{l}0.90 \pm 0.05 \\
{[4]}\end{array}$ & $\begin{array}{l}2.1 \pm 0.2 \\
{[4]}\end{array}$ & $\begin{array}{l}3.4 \pm 0.5 \\
{[5]}\end{array}$ \\
\hline $\begin{array}{l}\text { Adult } \\
\text { (18 weeks) }\end{array}$ & GK & $\begin{array}{l}2.5 \pm 0.1 \\
{[5]}\end{array}$ & $\begin{array}{l}2.6 \pm 0.2 \\
{[5]}\end{array}$ & $\begin{array}{l}0.06 \pm 0.01^{\mathrm{b}} \\
{[4]}\end{array}$ & $\begin{array}{l}576 \pm 71^{\mathrm{a}} \\
{[4]}\end{array}$ & $\begin{array}{l}0.61 \pm 0.04^{\mathrm{b}} \\
{[4]}\end{array}$ & $\begin{array}{l}1.7 \pm 0.2 \\
{[4]}\end{array}$ & $\begin{array}{l}4.3 \pm 0.2 \\
{[5]}\end{array}$ \\
\hline
\end{tabular}

basal plasma insulin concentration was drastically decreased as compared to age-related control values. Concerning the basal plasma glucagon level in the GK neonates, no significant difference was detected as compared to control values, except a limited but statistically significant increase on day 14 . In both groups, the neonates had higher plasma glucagon values than those found in GK and control fetuses (Table 1).

Light microscopy examination of pancreatic sections in the 4, 7 and 14-day-old GK neonates revealed no sign of insulitis or pancreatitis. Both beta and alpha cells were strongly and homogeneously stained with the anti-insulin and anti-glucagon sera. Beta cells were located in the central part of the islets and alpha cells in the periphery. Large islets, less frequent in GK pancreases, displayed well-preserved architecture with normal staining of beta and alpha cells. Isolated cells or clusters of beta and alpha cells were also found throughout the acinar tissue in both groups (Fig.1). The staining of connective tissues did not show any sign of fibrosis around or inside the islets of 4, 7 and 14-day-old GK rats.

Our results obtained in the 4-day-old pancreases by confocal microscopy revealed the existence of cells with coexisting insulin and glucagon in the same cytoplasm. However, either in the control or in the GK group, these cells constituted a very low percentage of all beta cells detected in the pancreas: the cells double-stained for insulin and glucagon represented $0.3 \%$ of beta cells in the control group ( 3 cells with double-staining out of 1298 beta cells) and $0.2 \%$ in the GK group ( 3 cells with double-staining out of 1364 beta cells). These data indicate that our estimation of the total beta-cell mass in the neonatal pancreases is not significantly biased by the contribution of endocrine cells storing both insulin and glucagon.

The relative beta-cell volume in the pancreas of GK neonates represented about $50 \%$ of that found in agerelated control pancreases (Table 2). In GK rats total beta-cell mass, as calculated by multiplying the pancreas weight by the relative beta-cell volume, was decreased by $65 \%$ on day 4 , by $70 \%$ on day 7 and $63 \%$ on day 14 as compared to the corresponding control values (Fig. 2). The fractional increase of total betacell mass between fetal age day 21.5 and postnatal age day 4, was found to be higher in GK rats than in controls (amounting to $366 \%$ in GK rats vs $202 \%$ in controls). During the last part of the first postnatal week (i.e. from day 4 to day 7), whereas the total beta-cell mass and the pancreatic insulin content showed a progressive increase in control newborns, these parameters remained unchanged in GK rats. By contrast, when calculated between day 4 and day 14 , the rate of beta-cell growth was found similar in both groups. It is therefore remarkable that the increase of beta-cell mass occurs essentially between day 4 and 


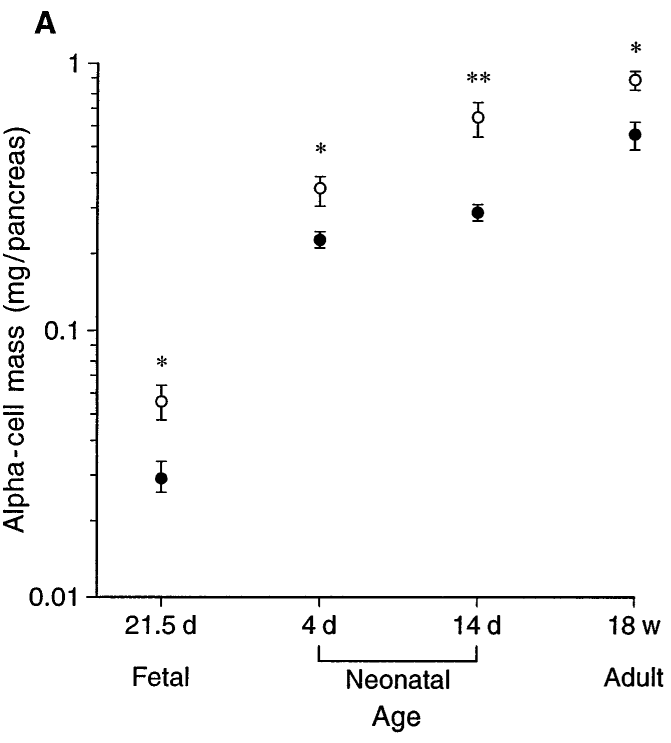

Fig. 3 A , B. Developmental changes of the alpha-cell mass in pancreas of Wistar $(\bigcirc)$ and GK $(O)$ rats between fetal age (day 21.5) and adult age (18 weeks) (means \pm SEM). A Alpha-cell mass per pancreas; B Alpha-cell mass per mg pancreas. $* p<0.05, * * p<0.01$ as compared to age-related controls

day 7 in the control rats while it occurs between day 7 and day 14 in the GK rats. The pancreatic insulin content was significantly lower in GK neonates as compared to controls at all ages studied (Table 2). Since the corresponding GK beta-cell masses were decreased to the same extent, the mean insulin content per beta cell in GK neonates was not significantly different from the value in control neonates, during the period day 4-day 14 after birth (Table 2). The individual cross-sectional area of the beta cells in the 7-dayold GK pancreases was not significantly different from the corresponding value in control rats (respectively $103 \pm 7$ and $97 \pm 5 \mu \mathrm{m}^{2}$ ). This indicates that the restriction of the total beta-cell mass found in the GK group can be mostly ascribed to beta-cell hypoplasia (and not to beta-cell hypotrophy).

Concerning the total alpha-cell mass as well as the pancreatic glucagon content, during the neonatal period (Table 3), their values were lower in GK rats as compared to age-related controls due to the lower pancreas weight in the GK neonates. Their alphacell mass and pancreatic glucagon content were found to be not significantly different from those of the age-related controls, when expressed as per unit pancreas mass (Fig. 3).

\section{A dults}

The 18-week-old male diabetic GK rats exhibited a significantly lower body weight as compared to agerelated non-diabetic Wistar controls. When examined

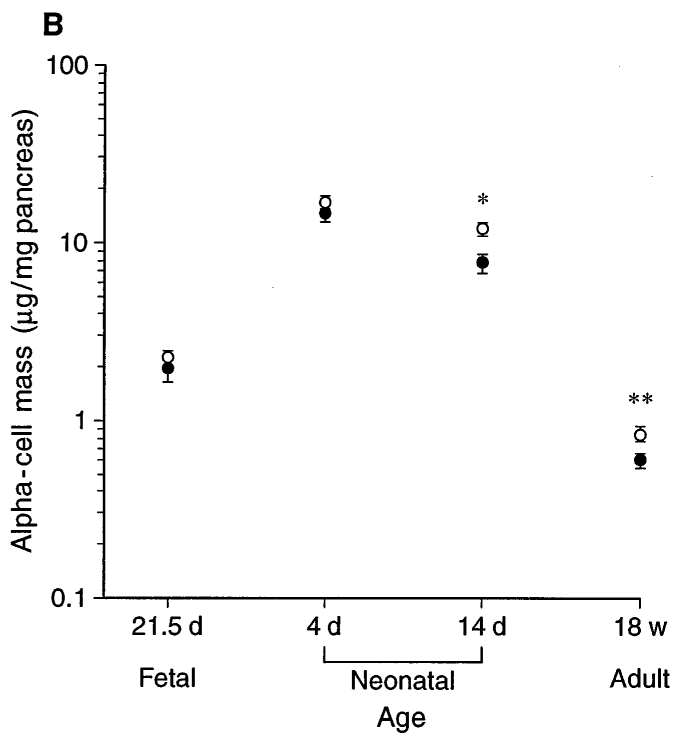

in the non-fasted state, their basal plasma glucose and insulin levels were found to be higher than those in the control rats. There was no significant difference in basal plasma glucagon level between the two groups. As compared to that in the neonates, plasma glucagon level in either GK or Wistar non-diabetic adult rats, was two times lower in accordance with data in the literature.

The GK pancreases exhibited no sign of insulitis or pancreatitis. Small islets were easily and homogeneously stained with anti-insulin and anti-glucagon sera, as in control pancreases. Conversely, almost all the large islets displayed irregular capsules and heterogeneity in the staining of beta cells within the same islet core (strongly labelled cells adjacent to weakly labelled ones) (Fig.1). Many of these large islets were disrupted showing fibrous strands and resembling starfish-shaped islets as originally described by Goto et al. [3]. The relative beta-cell volume and the total pancreatic beta-cell mass in the adult GK pancreas represented only 64 and $47 \%$ of control values, respectively. Also the pancreatic insulin content was significantly lower in GK rats as compared to controls, representing only $32 \%$ of control value. The insulin content per beta cell was similar in both groups of rats (Table 2).

Concerning the relative alpha-cell volume as well as the total alpha-cell mass, their values in the adult GK rats were found to be mildly but significantly decreased, representing 67 and $63 \%$ of controls, respectively (Fig.3). No significant difference was detected between the two groups concerning the glucagon content per alpha cell (Table 3).

\section{Discussion}

The aim of this work was to study the basal biological characteristics and the development of endocrine 
pancreas in GK rats in comparison to control nondiabetic Wistar rats.

In the control rats, the plasma insulin level at the end of fetal life was found to be very high as compared to those in newborn and adult rats in accordance with previous studies [14-16]. Concerning the plasma glucagon level, it reached its highest value during neonatal life when compared to the fetal and adult age, in confirmation of previous reports [14, 17]. Our morphometrical data concerning the normal development of the endocrine pancreas are also in good agreement with previously published data [1821]. In 4-day-old control rats as compared to 21.5day-old fetuses, the total pancreatic beta-cell mass was found to be strongly increased while the total pancreatic wet weight was not. This explained the greater beta-cell tissue/total pancreatic tissue ratio found in the newborn rat pancreas. In adult rats, while the absolute beta-cell mass was higher than in the neonates, the relative beta-cell volume was significantly lower than that of the neonate.

Concerning the alpha-cell development, their mass was greatly increased in the newborn as compared to the 21.5-day-old fetus. Actually, the fractional increase of the alpha-cell mass from fetal day 21.5 until day 14 after birth was three times higher than that of the beta cells (1047 vs $351 \%$ ). By contrast, when calculated from day 14 after birth until adult age, the fractional increase of alpha-cell mass was 15 times lower than that of the beta cells (38 vs $569 \%$ ). This indicates that the development and the growth of alpha cells was much faster than that of beta cells in the first 2 weeks after birth and that, later in life, the growth of alpha cells became less important, in agreement with previous report by $\mathrm{Mc}$ Evoy [20].

Concerning the GK model, our results showed that the overall fetal growth was normal since there was no difference in the body weight between GK and Wistar 21.5-day-old fetuses. GK fetuses had a higher glycaemia than control fetuses. This was related to the higher value of basal glycaemia in GK mothers at the end of pregnancy as compared to that of Wistar mothers [22]. Plasma insulin level in the 21.5-day-old GK fetuses was significantly decreased (by $50 \%$ ) as compared to controls while the plasma glucagon level in the GK fetuses was normal. After birth, GK pups exhibited growth retardation as attested by lower body weight and pancreas weight. The basal plasma glucose levels in the 4, 7 and 14day-old GK newborns were normal. Interestingly, despite normoglycaemia, the basal plasma insulin levels were very low in 4,7 and 14-day-old GK rats as compared to age-related control rats. Such a pattern suggests an enhanced tissue response to insulin in the GK pups as compared to controls, at least in the basal situation. Of course this assumption needs to be experimentally tested, but it is strengthened by our previous demonstrations in two different rat models of insulin deficiency, that insulin action in vivo is in fact enhanced under conditions with basal hypoinsulinism and normal glycaemia [23, 24]. Basal hyperglycaemia was indeed detectable in GK rats only after 3 weeks (J. Movassat and D. Bailbé, unpublished observation) and it remained thereafter [25, 26].

In the GK rat, our morphometrical investigation of the pancreas indicated a severe alteration in the growth of the beta-cell population, starting from the late fetal stage and still present in adulthood. As early as 21.5 days post coïtum, GK fetuses exhibited a lower pancreatic weight and total pancreatic beta-cell mass, the value of this last parameter representing in the GK fetuses only $23 \%$ of that of normal fetuses. It is known that the development of beta cells during intrauterine life mainly relies upon the neogenesis of beta cell from the putative precursor cells [27, 28]. One might suggest that a shortage of these putative cells at the early stage of development associated with the possible alteration of proliferative capacity of the beta cells could be a cause of the deficiency of the beta-cell mass observed in the 21.5-day-old GK fetuses.

After birth, the marked increase of beta-cell mass observed in the control rat during the first 4 postnatal days was also found in the GK newborn. In the normal pancreas, after birth, the replication of the preexisting beta cells represents an important mechanism contributing to the increase of beta-cell mass. In GK pancreas based on our determination of the fractional increase of the beta-cell mass between fetal day 21.5 and neonatal day 14 (633 in GK rats vs $351 \%$ in control rats) after birth, one may consider that the existing GK beta cells, once differentiated, are able to maintain a normal replicative capacity. Of course this point must be reinforced by more direct proof based on the evaluation of the incorporation of BrdU in the beta cells. Despite the prominent expansion of beta-cell mass in relative terms during the first postnatal week, the total beta-cell mass in the GK newborns remained two- to threefold lower than that of the age-related controls. Value of the total pancreatic insulin content showed a high correlation with that of the beta-cell mass in both GK and control groups.

When considering the aetiology underlying the decreased beta-cell mass and pancreatic insulin content in the GK fetuses and neonates, our results do not fit with those of other studies related to the development of the endocrine pancreas in the rat under the conditions of gestational diabetes. The very mild disturbance of basal blood glucose in the GK fetus is associated with growth retardation of the pancreas with poor development of the beta cells, a fetal pattern which is generally observed only in the context of severe diabetes with considerable hyperglycaemia and wasting of the mother (as obtained in spontaneous 
or streptozotocin diabetes or by glucose infusion) [29-36]. On the other hand, mild experimental diabetes during pregnancy in the rat has been reported to result in normal or even enhanced development of the fetal beta-cell mass $[31,32,35]$. Therefore the so far recognized notion that the degree of disturbance in the maternal (and fetal) metabolism is an important determinant of the amount of retardation of fetal beta-cell development does not apply to the GK model. This probably indicates that environmental factors reflecting the fetal hyperglycaemia are not major determinants for the retardation of beta-cell development in the GK model. One may rather suspect that genetic factors are the main contributors for this defect. In fact, preliminary data from our laboratory (P. Serradas, unpublished observation) indicate that beta-cell mass of fetuses issued from crossing experiments such as $\mathrm{W}$ father/GK mother or GK father/W mother, is very close to normal value (W/ W). A negligible or moderate impact of the uterine environment on the severity of diabetes in the GK adults, has also been mentioned previously [37, 38].

When the GK rats became adults, they exhibited basal mild hyperglycaemia and hyperinsulinaemia, in confirmation of previous results $[25,26]$. The reduced total beta-cell mass in the adult GK rats was associated with noticeable alteration in the architecture of the large islet subpopulation which displayed fibrosis together with signs of disorganization of the mantle-core relationship. Prominent connective tissue proliferation was seen in these enlarged islets in which clusters of beta cells were widely separated from each other by strands of fibrotic tissue. These morphological features in the endocrine pancreas of the adult GK rat are reminiscent of those reported in the adult GK animals from the Sendaï colony [3] and the Stockholm colony [10], in the spontaneously hyperglycaemic OLETF rat [39], in the 1-year-old male Sprague-Dawley rat [40], in the Zucker fatty rat [41] and in the rabbit after pancreatic duct ligation [42]. In the GK rat, it is interesting to notice that the islet fibrosis is not a primary event but it can rather be considered as a consequence of the installation of hyperglycaemia since it is not detectable in the islets of the neonatal animals. In this circumstance one may imagine that the hyperglycaemic stress on the pancreatic beta cells leads to their damage in some islets of the GK rats, cell death and infiltration of connective tissue.

Our present study also provides for the first time a chronicle of the pathophysiologic changes that occur in the GK rats starting from the late fetal period. The 4,7 or 14-day-old GK pups demonstrated normal basal glycaemia as compared to age-related Wistar rats. However, their total beta cell mass was significantly below (decreased by more than $60 \%$ ) that of the controls. These data indicate that a reduction in islet tissue clearly predates the onset of diabetes (hyperglycaemia). Since such a defect is in fact still present in utero, a reduction of the total beta-cell mass must be considered as a primary feature in the pathological sequence leading to diabetes in the GK rats, at least those originating from the Paris colony. Taken as a whole, our present knowledge of the pathogenesis of diabetes in the GK rats of the Paris colony suggests that, to impaired insulin secretion $[6$, $25]$ and insulin resistance [25, 26], should be added a third factor with a primary aetiologic role, impaired beta-cell development.

Concerning the development of alpha cells, their total pancreatic mass was lower in GK rats than in controls at all ages investigated. The decrease of the alpha-cell mass was directly related to the decrease of pancreatic weight in GK rats, at least before day 14. Thereafter, the relative alpha-cell mass (in $\mu \mathrm{g}$ alpha-cell per $\mathrm{mg}$ pancreatic tissue) remained decreased in the GK as compared to age-related control rats. In addition, the decrease of the alpha-cell mass appears rather late as compared to that of the beta cells. It is conceivable that the decrease of the alphacell mass could be partly due to the disorganization of the normal islet architecture and the development of fibrosis, two parameters which may participate in the perturbation of islet blood flow previously described in the adult GK model [43, 44] and in doing so also affecting the alteration of endocrine insular cell growth.

In conclusion our results demonstrate that in the GK rat, a genetic model of NIDDM: 1) as early as fetal age there is an alteration of beta cell development; 2) the deficit of total pancreatic beta-cell mass is maintained in the adult animal; 3) while early development of the alpha cells is not affected, their relative mass becomes secondarily decreased. In the context of restricted beta-cell mass as a very early hallmark in the sequence of events leading to overt diabetes in the GK model, it now becomes necessary to pay more attention to the role of altered beta-cell neogenesis and/or beta-cell replication. Available information on rodents suggests that limitations of the size of the proliferative beta-cell compartment determine whether compensatory growth will be successful $[45,46]$. As this capacity depends among others on genetic factors, it is conceivable that several genes among the set causing diabetes in the GK rat [47] are responsible for impaired beta-cell growth.

A cknowledgements. This work was supported by a grant from the Institut Lilly-France (contrat de recherche en Diabétologie ALFEDIAM/LILLY 1994). We are grateful to Danielle Bailbé for expert assistance in the GK rat breeding, and to Gérard Géraud and the Service d'Imagerie - Institut J. Monod - University Paris 7/D. Diderot for providing confocal microscopy facilities. J. M. is a recipient of a fellowship from the Ministère de l'Education Nationale, de l'Enseignement Supérieur et de la Recherche (allocation de recherche ${ }^{\circ} 14314$ ). 


\section{References}

1. Klöppel G, Löhr M, Hablich K, Oberholzer M, Heitz PU (1985) Islet pathology and pathogenesis of type I and type II diabetes revisited. Surv Synth Path Res 4: 110-125

2. Leahy JL (1990) Natural histology of B-cell dysfunction in NIDDM. Diabetes Care 13: 992-1010

3. Goto Y, Suzuki K, Sasaki M, Ono T, Abe S (1988) GK rats as a model of nonobese, non-insulin-dependent diabetes: selective breeding over 35 generations. In: Shafrir E, Renold AE (eds) Frontiers in diabetes research. Lessons from animal diabetes II. Libbey, London, pp 301-303

4. Berthelier C, Picarel F, Kergoat M, Portha B (1995) Ageing, glucose metabolism and insulin action in the diabetic GK rat. Comparison with the normal Wistar rat. Diabetologia [Suppl 1] 38: 530A (Abstract)

5. Movassat J, Saulnier C, Portha B (1995) $\beta$-cell mass depletion precedes the onset of hyperglycaemia in the GK rat, a genetic model of non-insulin-dependent diabetes mellitus. Diabete Metab 21: 365-370

6. Portha B, Giroix MH, Serradas P, Morin L, Tormo MA, Bailbé D (1994) Cellular basis of pancreatic B-cells in non-insulin-dependent diabetes. In: Flatt PR, Lenzen S (eds) Insulin secretion and pancreatic B-cell research. Smith-Gordon, London, pp 461-472

7. Östenson CG, Khan A, Abdel-Halim SM et al. (1993) Abnormal insulin secretion and glucose metabolism in pancreatic islets from the spontaneously diabetic GK rat. Diabetologia 36: 3-8

8. Hughes SJ, Suzuki K, Goto Y (1994) The role of islet secretory function in the development of diabetes in the GK Wistar rat. Diabetologia 37: 863-870

9. Östenson CG, Abdel-Halim SM, Rasschaert J et al. (1993) Deficient activity of FAD-linked glycerophosphate dehydrogenase in islets of GK rats. Diabetologia 36: 722-726

10. Guenifi A, Abdel-Halim SM, Höög A, Falkmer S, Östenson CG (1995) Preserved B-cell density in the endocrine pancreas of young, spontaneously diabetic Goto-Kakizaki (GK) rats. Pancreas 10: $148-153$

11. Michel C, Chariot J, Souchard M, Roze C (1982) Modifications of the endocrine pancreas in rats after ethionine destruction of acini. Cell Mol Biol 28: 135-148

12. Heidenhain M (1915) Uber die Mallorysche Bundegewebsfärbung mit Karmin und Azokarmin als Vorfarben. Z.wiss. Mikroskop 32: 361-372

13. Montana E, Bonner-Weir S, Weir GC (1994) Transplanted beta cell response to increased metabolic demand. Changes in beta cell replication and mass. J Clin Invest 93: 1577-1582

14. Portha B, Picon L, Rosselin G (1978) Postmaturity in the rat: high levels of glucagon in the plasma of the foetus and neonates. J Endocr 77: 153-154

15. Sodoyez-Goffaux FR, Sodoyez JC, De Vos CJ (1979) Insulin secretion and metabolism during the perinatal period in the rat. J Clin Invest 63: 1095-1102

16. Ktorza A, Girard JR, Kinebanyan MF, Picon L (1981) Hyperglycaemia induced by glucose infusion in the unrestrained pregnant rat during the last three days of gestation: metabolic and hormonal changes in the mother and the fetuses. Diabetologia 21: 569-574

17. Girard J, Kervran A, Soufflet E, Assan R (1974) Factors affecting the secretion of insulin and glucagon by the rat fetus. Diabetes 23 : 310-317

18. McEvoy RC, Madson KL (1980) Pancreatic insulin, glucagon and somatostatin-positive islet cell population during the perinatal development of the rat. I-Morphometric quantitation. Biol Neonate 38: $248-254$

19. McEvoy RC, Madson KL (1980) Pancreatic insulin, glucagon and somatostatin-positive islet cell population during the perinatal development of the rat. II-Changes in hormone content and concentration. Biol Neonate 38: 255-259

20. McEvoy RC (1981) Changes in the volumes of the A-, B-, and Dcell populations in the pancreatic islets during the postnatal development of the rat. Diabetes 30: 813-817

21. Wang RN, Bouwens L, Klöppel G (1994) Beta-cell proliferation in normal and streptozotocin-treated newborn rats: site, dynamics and capacity. Diabetologia 37: 1088-1096

22. Serradas P, Welsh N, Saulnier C et al. (1993) Islet function and mitochondrial gene expression in the adult and fetal endocrine pancreas of diabetic GK rats. Diabetologia 36 [Suppl 1]: 326A (Abstract)

23. Kergoat M, Guerre-Millo M, Lavau M, Portha B (1991) Increased insulin action in rats with mild insulin deficiency induced by neonatal streptozotocin. Am J Physiol 23: 561-567

24. Escriva F, Kergoat M, Bailbé D, Pascual-Leone A-M, Portha B (1991) Increased insulin action in the rat after protein malnutrition early in life. Diabetologia 34: 559-564

25. Picarel-Blanchot F, Berthelier C, Bailbé D, Portha B (1996) Impaired insulin secretion and excessive hepatic glucose production are both early events in the diabetic GK rat. Am J Physiol 34: E755-E762

26. Bisbis S, Bailbé D, Tormo MA, Picarel-Blanchot F, Derouet M, Simon J, Portha B (1993) Insulin resistance in the GK rat: decreased receptor number but normal kinase activity in liver. Am J Physiol 265:E807-E813

27. Bonner-Weir S (1994) Regulation of pancreatic $\beta$-cell mass in vivo. Recent Progress in Hormone Research 49: 91-104

28. Bouwens L, Klöppel G (1996) Islet cell neogenesis in the pancreas. Virchows Arch 427: 553-560

29. Verhaeghe J, Peeters T, Vandeputte M, Rombauts W, Bouillon R, Van Assche F (1989) Maternal and fetal endocrine pancreas in the spontaneously diabetic BB rat. Biol Neonate 55: 298-308

30. Pitkin RM, Van Orden DE (1974) Fetal effect of maternal streptozotocin-diabetes. Endocrinology 94: 1247-1253

31. Aerts L, Van Assche FA (1977) Rat foetal endocrine pancreas in experimental diabetes. J Endocr 73: 339-346

32. Kervran A, Guillaume M, Jost A (1978) The endocrine pancreas of the fetus from diabetic pregnant rat. Diabetologia 15: 387-393

33. Eriksson U, Andersson A, Efendic S, Elde R, Hellerström C (1980) Diabetes in pregnancy: effects on the foetal and newborn rat with particular regard to body weight, serum insulin concentration and pancreatic contents of insulin, glucagon and somatostatin. Acta Endocr 94: 354-364

34. Swenne I, Eriksson U (1982) Diabetes in pregnancy: islet cell proliferation in the fetal rat pancreas. Diabetologia 23: 525-528

35. Eriksson U, Swenne I (1982) Diabetes in pregnancy: growth of the fetal pancreatic B cells in the rat. Biol Neonate 42: 239-248

36. Bihoreau MT, Ktorza A, Kervran A, Picon L (1986) Effect of gestational hyperglycemia on insulin secretion in vivo and in vitro by fetal rat pancreas. Am J Physiol 251: E86-E91

37. Abdel-Halim S, Guenifi A, Luthman H, Grill V, Efendic S, Östenson C-G (1994) Impact of diabetic inheritance on glucose tolerance and insulin secretion in spontaneously diabetic GK-Wistar rats. Diabetes 43: 281-288

38. Gauguier D, Nelson I, Bernard C et al. (1994) Higher maternal than paternal inheritance of diabetes in GK rats. Diabetes 43: 320-324

39. Shima K, Shi K, Sano T, Iwami T, Mizuno A, Noma Y (1993) Is exercise training effective in preventing diabetes mellitus in the Otsuka-Long-Evans-Tokushima-Fatty rat, a model of spontaneous non-insulin-dependent diabetes mellitus? Metabolism 42: 971-977

40. Reaven EP, Reaven GM (1981) Structure and function changes in the endocrine pancreas of aging rats with reference to the modulating effects of exercise and caloric restriction. J Clin Invest 68: 75-84

41. Shino A, Matsuno T, Iwatsuka H (1973) Structural changes of pancreatic islets in genetically obese rats. Diabetologia 9: 413-421

42. Catala J, Bonnafous R, Hollande E (1986) Disturbances in the regulation of glycaemia in rabbits following pancreatic duct ligation biochemical and immunocytochemical studies. Diabète Métab 12: 203-211

43. Atef N, Portha B, Pénicaud L (1994) Changes in islet blood flow in rats with NIDDM. Diabetologia 37: 677-680

44. Svensson A, Östenson C-G, Sandler S, Efendic S, Jansson L (1994) Inhibition of nitric oxide synthase by $\mathrm{N}$-nitro-L-arginine causes a preferential decrease in pancreatic islet blood flow in normal rats and spontaneously diabetic GK rats. Endocrinology 135: 849-853

45. Swenne I, Andersson A (1984) Effect of genetic background on the capacity for islet cell replication in mice. Diabetologia 27: 464-467

46. Zhu M, Noma Y, Mizuno A, Sano T, Shima K (1996) Poor capacity for proliferation of pancreatic $\beta$-cells in Otsuka-Long-Evans-Tokushima-Fatty rat. Diabetes 45: 941-946

47. Gauguier D, Froguel P, Parent V et al. (1996) Genetic dissection of non insulin dependent diabetes in the GK rat. Nature Genet 12: $38-43$ 